\title{
Neoliberal Urbanization in E urope: Large-Scale Urban Development Projects and the New Urban Policy
}

\author{
E rik Swyngedouw
}

School of G eography and the E nvironment, Oxford U niversity, Oxford, UK ;

St Peter's College, Oxford, U K ; erik.swyngedouw@ geography.ox.ac.uk

\section{Frank Moulaert}

F aculty of Sociology and E conomics, U niversity of Lille I, Lille, France; Institut F édératif de R echerche sur les É conomies et les Sociétés I ndustrielles

(IFRÉ SI ), Lille, France; frank.moulaert@ ifresi.univ-lille1.fr

\begin{abstract}
and
Arantxa Rodriguez

Department of A pplied E conomics, U niversity of the Basque Country,

Bilbao, Spain; euproala@bs.ehu.es
\end{abstract}

This paper summarizes the theoretical insights drawn from a study of thirteen largescale urban development projects (UDPs) in twelve European U nion countries. The project focused on the way in which globalization and liberalization articulate with the emergence of new forms of governance, on the formation of a new scalar gestalt of governing and on the relationship between large-scale urban development and political, social and economic power relations in the city. A mong the most important conclusions, we found that:

- Large-scale UDPs have increasingly been used as a vehicle to establish exceptionality measures in planning and policy procedures. This is part of a neoliberal "New U rban Policy" approach and its selective "middle- and upperclass" democracy. It is associated with new forms of "governing" urban interventions, characterized by less democratic and more elite-driven priorities.

- Local democratic participation mechanisms are not respected or are applied in a very "formalist" way, resulting in a new choreography of elite power. However, grassroots movements occasionally manage to turn the course of events in favor of local participation and of modest social returns for deprived social groups.

- The UDPs are poorly integrated at best into the wider urban process and planning system. A s a consequence, their impact on a city as a whole and on the areas where the projects are located remains ambiguous.

- Most UDPs accentuate socioeconomic polarization through the working of real-estate markets (price rises and displacement of social or low-income 
housing), changes in the priorities of public budgets that are increasingly redirected from social objectives to investments in the built environment and the restructuring of the labor market.

- The UDPs reflect and embody a series of processes that are associated with changing spatial scales of governance; these changes, in turn, reflect a shifting geometry of power in the governing of urbanization.

\section{Large-Scale Urban Development Projects as Urban Policy}

O ver the past fifteen years or so, local authorities-alone or in concert with the private sector-have strongly relied on the planning and implementation of large-scale urban development projects (UDPs), such as museums, waterfronts, exhibition halls and parks, business centers, and international landmark events, as part of an effort to re-enforce the competitive position of their metropolitan economies in a context of rapidly changing local, national, and global competitive conditions. In many cases, these projects were supported by a majority of the local constituency, or at least by a silent majority. I n other cases, they were initiated by means of "exceptionality" measures, such as the freezing of conventional planning tools, bypassing statutory regulations and institutional bodies, the creation of project agencies with special or exceptional powers of intervention and decision-making, and/or a change in national or regional regulations. On occasion, national governments became the main developers, setting aside both local authorities and constituencies.

This paper will examine the dynamics that have accompanied the implementation of large-scale U D Ps in thirteen E uropean cities within the E uropean $U$ nion (EU ). The analysis is based on research undertaken as part of a Targeted Socioeconomic R esearch A ction (Framework IV program of the EU), "U rban Restructuring and Social Polarization in the City" (UR SPIC). U R SPIC examined whether largescale UDPs, as emblematic examples of neoliberal forms of urban governance, contribute to accentuating processes of social exclusion and polarization, or whether they foster social integration and promote integrated urban development. ${ }^{1}$ The project intended to contribute to the analysis of the relationship between urban restructuring and social exclusion/integration in the context of the emergence of the new regimes of urban governance that parallel the European-wide-albeit geographically uneven and, on occasion, politically contestedconsolidation of a neoliberal and market-driven ideology and politics. The selected UD Ps embody and express processes that reflect global pressures and incorporate changing systems of local, regional, and/or national regulation and governance. These projects, while being decidedly local, capture global trends, express new forms of national and local policies, and incorporate them in a particular localized setting. The selected U D Ps are listed in Table 1 according to their city's ranking 


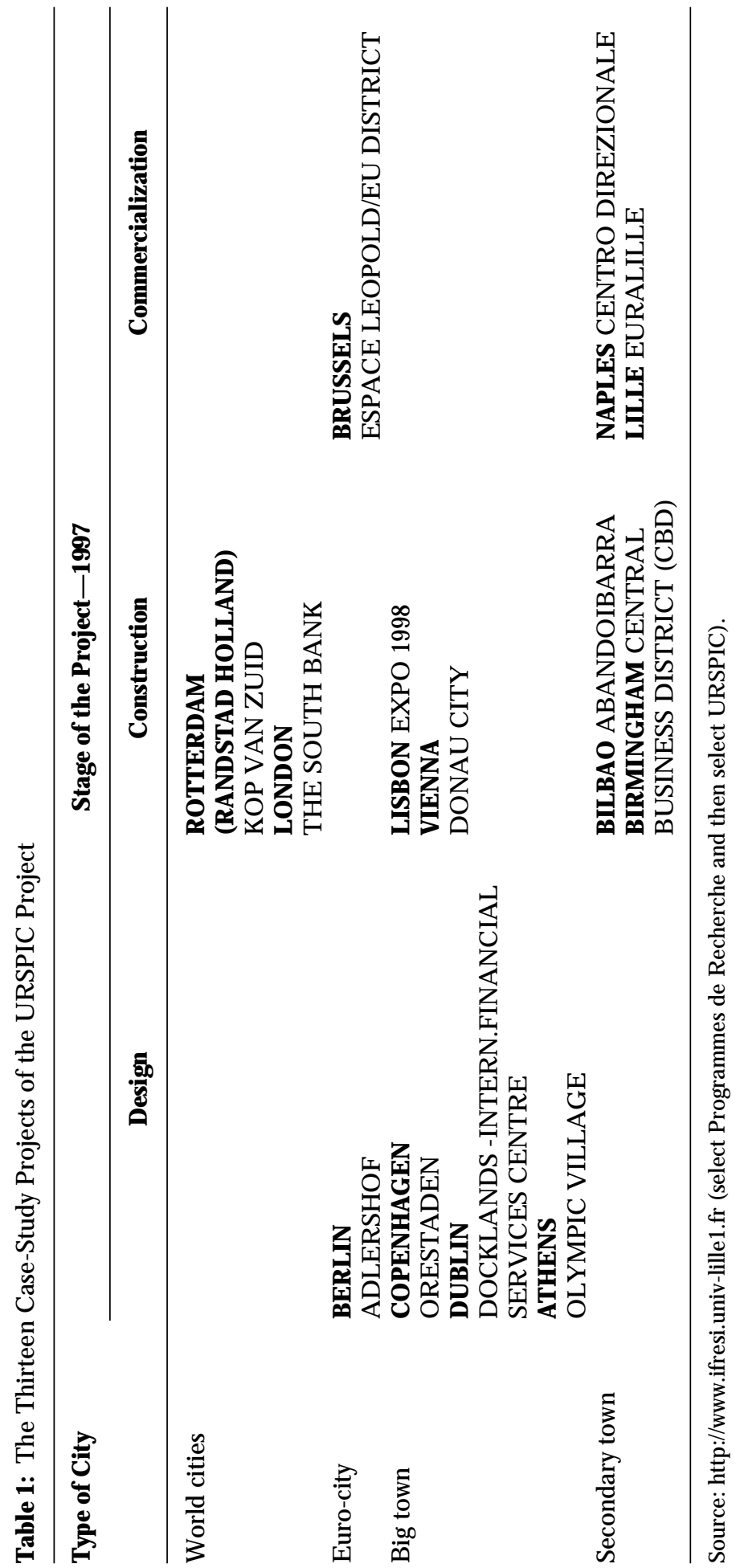


in the world urban hierarchy and their stage of development at the start of the research project in 1997.

\section{Reordering the Urban: Large-Scale UDPs and the "G localisation" of the City}

Cities are, of course, brooding places of imagination, creativity, innovation, and the ever new and different. However, cities also hide in their underbelly perverse and pervasive processes of social exclusion and marginalization and are rife with all manners of struggle, conflict, and often outright despair in the midst of the greatest affluence, abundance, and pleasure. These dynamics that define the urban experience have, if anything, taken on a heightened intensity over the past two decades or so. There is no need to recount here the tumultuous reordering of urban social, cultural, and economic life that has rampaged through the city. $M$ any urban communities have been left in the doldrums of persistent decline and permanent upheaval and are still faced with the endless leisure time that comes with lasting unemployment. Others have risen to the challenge that restructuring sparks off and have plunged into the cracks and fissures that have opened up a vast arena of new possibilities of action and intervention, as governments and economies desperately seek out new niches for revitalizing the urban fabric.

These urban transformations, exhaustively documented in many academic research and governmental documents, have invariably been situated in the context of a transforming spatial political, sociocultural, and economic system. While economic processes were rapidly globalizing and cities were trying to carve out their niche within the emerging new divisions of labor, of production, and of consumption, political transformations-pursued by local, regional, and national governments of all ideological stripes and colors-were initiated in an attempt to align local dynamics with the imagined, assumed, or real requirements of a deregulated international economic system, whose political elites were vigorously pursuing a neoliberal dogma. Heralded by some as the harbinger of a new era of potential prosperity and vilified by others as the source of enduring restructuring and accentuated social polarization and marginalization, the urban arena became a key space in which political-economic and social changes were enacted. The new urban policy, developing in parallel with the new neoliberal economic policy, squarely revolved around re-centering the city. O Id forms and functions, traditional political and organizational configurations, had to give way to a new urbanity, a visionary urbanity that would stand the tests imposed by a global and presumably liberal world order. Repositioning the city on the map of the competitive landscape meant reimagining and recreating urban space, not just in the eyes of the master planners and city fathers and mothers, but primarily for 
the outsider, the investor, developer, businesswoman or -man, or the money-packed tourist.

The urban turned into ruin in the devastating restructuring of the 1970 s and 1980s. R ebuilding the city-as in the aftermath of a warbecame the leitmotif of urban policy. Large-scale and emblematic projects were the medicine the advocates of the new urban policy prescribed. A ccommodation of the $E U$ 's encroaching office expansion in Brussels, the Guggenheim museum in Bilbao, the new financial district in the Dublin's docklands, the science-university complex A dlershof in Berlin, Copenhagen's O restaden project, and the 1998 World Expo in Lisbon, among many other examples that are dotted over the map of urban E urope, testify to the unshakeable belief of the city elites in the healing effects that the production of new urban complexes promises for the city's vitality.

While we agree that large-scale U D Ps have indeed become one of the most visible and ubiquitous urban revitalization strategies pursued by city elites in search of economic growth and competitiveness, we also insist that it is exactly this sort of new urban policy that actively produces, enacts, embodies, and shapes the new political and economic regimes that are operative at local, regional, national, and global scales. These projects are the material expression of a developmental logic that views megaprojects and place-marketing as means for generating future growth and for waging a competitive struggle to attract investment capital. U rban projects of this kind are, therefore, not the mere result, response, or consequence of political and economic change choreographed elsewhere. On the contrary, we argue that such U DPs are the very catalysts of urban and political change, fuelling processes that are felt not only locally, but regionally, nationally, and internationally as well. It is such concrete interventions that express and shape transformations in spatial political and economic configurations. They illustrate the actual concrete process through which postmodern forms, post-Fordist economic dynamics, and neoliberal systems of governance are crafted and through which a new articulation of regulatory and governmental scales is produced. UDPs are productive of and embody processes that operate in and over a variety of scales, from the local to the regional, the national, the European, and the global scale. From our vantage point, the urban project becomes the lens that permits the casting of light on (1) how the scalar interplay is etched into particular urban schemes; (2) how these projects, in turn, express the way forces operating at a variety of geographical scales intersect in the construction of new socioeconomic environments; and (3) how social polarization and exclusion/integration, as well as processes of empowerment/disempowerment, are shaped by and work through these forms of sociospatial restructuring. 
This paper attempts to provide a panoramic view of changes in urban development strategies and policies in some of E urope's greatest cities. While being sensitive to the formative importance of local and national configurations, the case studies also suggest a series of similarities that point to a more general process of urban socioeconomic restructuring and of reorganization of the system of governance. The localization of the global and the globalization of the local become crafted in place-specific forms, yet they show perplexing-and often disturbing-common threads. In many ways, therefore, urban environments as constructed places are the condensed expression and incarnation of the transformation of sociospatial processes that operate on a variety of articulated geographical scales.

\section{Urban Redevelopment Strategies in the E uropean City: Autocratic G overnance, M onumental Spaces, and $M$ ythical Imaginations}

A N ew U rban Policy (NUP)? The Search for G rowth and Competitive Restructuring

Despite the differences between the case-study projects and the distinct political-economic and regulatory regimes of which they are part, they share a new approach in urban policy that strongly expresses, at the scale of the urban, the main ingredients of a $\mathrm{New}$ E conomic Policy (NEP). N ew E conomic Policy is the policy platform of conservative liberalism. Contrary to what its ideology sustains, conservative liberalism has always maintained a very special and intimate relationship with state intervention (see K eil this volume). It seeks to reorient state intervention away from monopoly market regulation and towards marshaling state resources into the social, physical, and geographical infra- and superstructures that support, finance, subsidize, or otherwise promote new forms of capital accumulation by providing the relatively fixed territorial structures that permit the accelerated circulation of capital and the relatively unhindered operation of market forces. At the same time, the state withdraws to a greater or lesser extent from socially inclusive blanket distribution-based policies and from Keynesian demand-led interventions and replaces them with spatially targeted social policies and indirect promotion of entrepreneurship, particularly via selective deregulation, stripping away red tape, and investment "partnerships" (see Peck and Tickell this volume). The relationship between NEP, N ew U rban Policy (NU P), and U D Ps is summarized in Figure 1 and will be explored further in the subsequent sections of this paper.

One of the key components of the new mode of socioeconomic regulation in cities has been a gradual shift away from distributive policies, welfare considerations, and direct service provision towards 


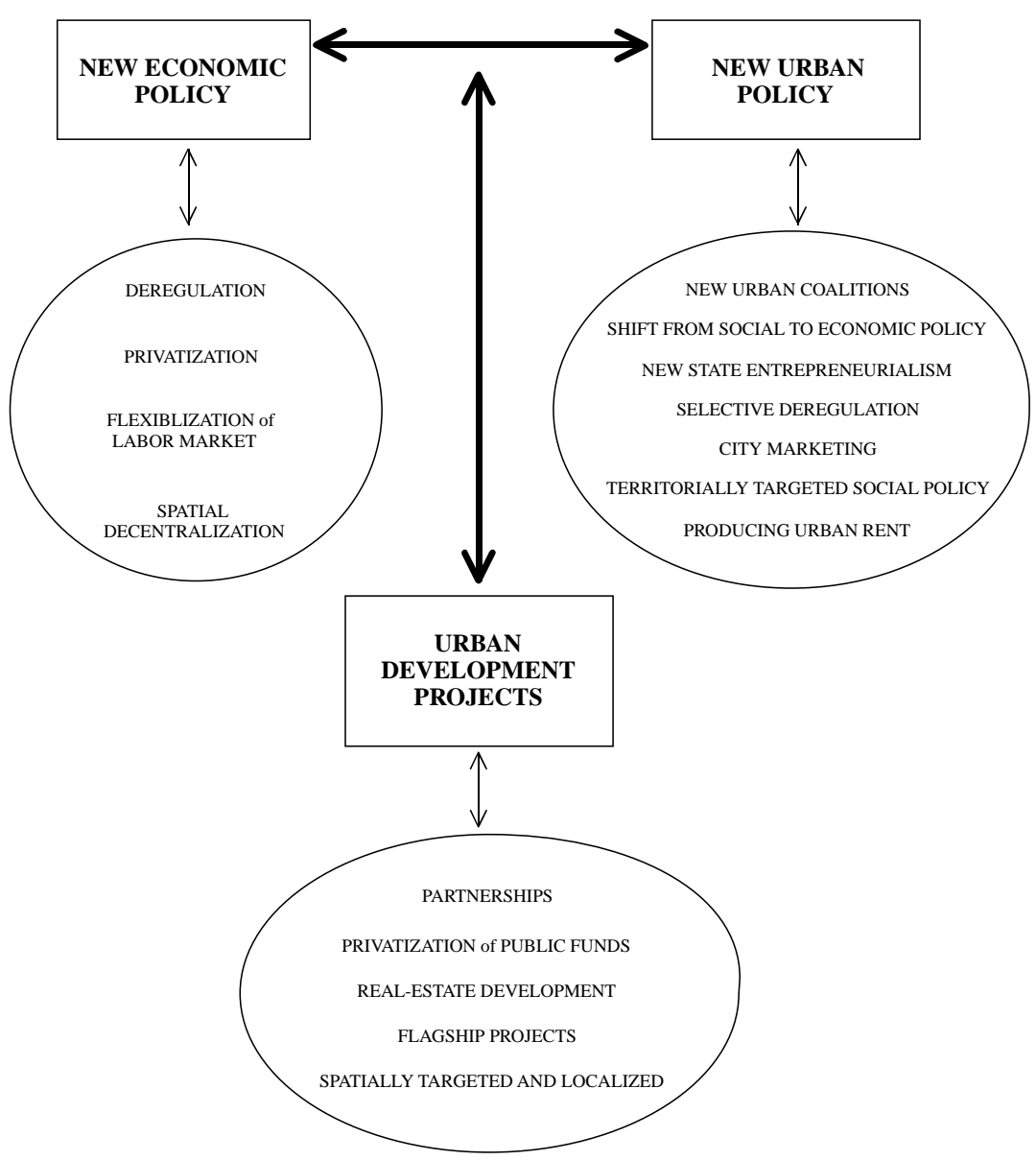

Figure 1: R elationship between NEP, NUP, and UDPS

more market-oriented and market-dependent approaches aimed at pursuing economic promotion and competitive restructuring. In most cities, urban revitalization is presented as an opportunity to change economic hierarchies and functions within the urban region, creating new jobs and strengthening the city's position in the urban division of labor. In this way, the search for growth turns urban renewal into a mediated objective, a necessary precondition for economic regeneration. Although this general trend takes quite distinct forms in different cities (see Table 2 for a description of six of these projects), projectbased urban interventions generally involve critical changes in priorities and the ascent of a more assertive, dynamic, and entrepreneurial style of urban governance. Planners and local authorities adopt a more proactive and entrepreneurial approach aimed at identifying market opportunities and assisting private investors to take advantage 
Table 2. The R ole of U D Ps in the City's G rowth Strategy: M ain Functions and D evelopment Logic for Six Projects

\begin{tabular}{ccc}
\hline Project & $\begin{array}{c}\text { Size and Location } \\
\text { New Functions }\end{array}$ & Main Development Logic
\end{tabular}

$\begin{array}{ll}\text { Berlin } & \text { The development area is } \\ \text { A dlershof } & \text { located in an outlying district } \\ \text { (Treptow) in the Southeast of } \\ \text { Berlin, } 12 \mathrm{~km} \text { from the center. } \\ \text { It is connected to the suburban } \\ \text { rail network. } \\ \text { The area encompasses } \\ \text { approximately } 420 \text { ha, with a } \\ \text { site for science (R \& D } \\ \text { activities), a business area, a } \\ \text { M edia City, a university } \\ \text { campus, a park, sites for trade } \\ \text { and industry, and several } \\ \text { residential areas. }\end{array}$

Bilbao A bandoibarra is a waterfront A bandoibarra site of $345.000 \mathrm{~m}^{2}$ located in the heart of the city of Bilbao. Situated strategically on the edge of the 19th-century expansion of the city, one of the highest income neighborhoods.

The site is presented as the new cultural and business center for Bilbao. Two major sites, the Guggenheim M useum and the E uskalduna Conference and Concert $\mathrm{H}$ all, are the key landmarks of a project that also includes the construction of $80.000 \mathrm{~m}^{2}$ for office space, a 27.000- $\mathrm{m}^{2}$ shopping center, a luxury hotel, university facilities, and 800 housing units, as well as an additional $122.000 \mathrm{~m}^{2}$ of green areas.
Brussels
Leopold
Quarter
(Q uartier
Leopold)

U rban renewal logic. I ts main objectives are the restructuring of old industrial areas, the promotion of a future vision for an improved labor market based around high-technology and advances services, and supporting the formation of small innovative businesses in the field of technology, to create new urban mix of science, economy, media services, living, and leisure.

U rban renewal logic. The project aims to create a new directional center to lead economic regeneration in a declining industrial region/city; promote a postindustrial and international city, create a new economic structure, foster diversification of the urban sectoral mix, and support job creation in new and presumably dynamic and growth-oriented sectors such as culture and leisure.

From the developers' point of view: capital accumulation facilitated by the rapid E uropeanization and internationalization of Brussels. 
Table 2: Continued

\begin{tabular}{ccc}
\hline Project & $\begin{array}{c}\text { Size and Location } \\
\text { New Functions }\end{array}$ & M ain Development Logic
\end{tabular}

$O$ riginally conceived as an upper-class residential area, it is now one of the main office areas of Brussels and the central area for the expansion of a proliferating $E U$-related administration. It is served by an underground line and two railway stations.

\begin{tabular}{|c|c|}
\hline \multirow[t]{2}{*}{$\begin{array}{l}\text { Dublin } \\
\text { D ocklands } \\
\text { D evelopment } \\
\text { Project (with } \\
\text { International } \\
\text { Financial } \\
\text { Services } \\
\text { Centre [IFSC } \\
\text { as flagship) }\end{array}$} & $\begin{array}{l}\text { O riginal area covered } 11 \text { ha } \\
\text { of downtown docklands on the } \\
\text { north side of the river, which } \\
\text { runs through the city center. } \\
\text { This was subsequently widened } \\
\text { to } 29 \text { ha and was recently } \\
\text { extended to cover all } 500 \text { ha } \\
\text { of the port area on both sides } \\
\text { of the river. }\end{array}$ \\
\hline & $\begin{array}{l}\text { D evelopment of IFSC on the } \\
\text { north side of the river; continued } \\
\text { mix of residential, business, } \\
\text { service and cultural activities } \\
\text { on both sides of the river. }\end{array}$ \\
\hline
\end{tabular}

\section{Naples}

Centro

Direzionale (CD)
110 ha immediately east of the city center. The area is adjacent to the main railway station and well connected via major roads to the city harbor, airport, and motorway network. $O$ nly half of the area has actually been developed.

$M$ ixed uses: mainly offices for public institutions (courts, regional parliament and related functions, Public R egister, fire-brigade headquarters, church,
From the perspective of local government: to assure the continuing presence and facilitate the further expansion of E uropean $U$ nion and related international institutions. $M$ ain objectives are: to provide office space to the $E U$ and to whatever clients are attracted by B russels' status as E uropean capital; to reaffirm Brussels' role as E urope's capital and to cash in on the economic impact this has; and to raise the political and cultural position of the city in the E uropean urban hierarchy.

E conomic growth for original site; social and economic growth and physical regeneration for extended 500-ha site (of which only about 100 ha are in need of redevelopment).

Discourse of modernization to create a postindustrial city. Because of its mixed use, the $C D$ is supposed to contribute to the economic regeneration of the city and to improve its urban quality. A s host location of public and private service activities, the CD is also supposed to decrease congestion in the historical city center. 
Table 2: Continued

\begin{tabular}{ccc}
\hline Project & $\begin{array}{c}\text { Size and Location } \\
\text { New Functions }\end{array}$ & Main Development Logic
\end{tabular}

school, etc), but also offices for business, commercial activities, and sport facilities. R esidence accounts for $30 \%$ of the total built volume.

Vienna Donau City

The D onau-City (a
multifunctional UDP) is
located near the $D$ anube,
covering a subcenter with a
size of about 17.4 ha. The
housing projects on the same
riverside cover $41,507 \mathrm{~m}^{2}$.
The development axis-
L asallestrasse- runs across
the D anube and connects the
D onau-City with the inner city
and the surrounding
microregions on both
riversides.

Commercial and residential development: housing (1500 subsidized flats), offices, shopping, leisure and cultural facilities, school and university buildings, research and development park, apartment hotel.
Presented as a "bridge to the future," fostering economic growth and the formation of an international image for $V$ ienna; strong emphasis on symbolic capital formation

The D onau-C ity (including the $V$ iennese site of the $U$ nited Nations O rganization (U N O)) is regarded as a flagship for $V$ ienna, aimed at strengthening its role as an "international meeting place." The development axis is supposed to attract international business and foster and act as pivotal point in E ast-W est (E uropean) trade and investment; it offers housing for upper classes.

of them. Table 2 also summarizes the developmental view promoted by the city's economic and political elites and the associated boosterist discourses that legitimize the projects and the associated institutional and regulatory framework.

\section{State-led or State-based: The M yth of the Absent State} In contrast to discourses of market-led and entrepreneurial activity (risk taking, market-led investments), the UDPs are decidedly and almost without exception state-led and often state-financed. In a context of a liberalizing E uropean metagovernance by the E uropean Commission, of national deregulation, of shrinking or stable social redistributional policies, of the outright exclusion of some groups at the national or EU level (for example, immigrants), and of an often narrowing fiscal basis for local urban intervention, UDPS are 
marshaled as panaceas to fight polarization, to reinvigorate the local economy, and, most importantly-an explicit goal of these projectsto improve the tax basis of the city via a sociospatial and economic reorganization of metropolitan space. In some cases-such as Lille, R otterdam, B russels, Copenhagen, or Birmingham-a mix of projects is presented. Regardless of the efficacy of such a mix, the main objective of these projects is to obtain a higher social and economic return and to revalue prime urban land. The production of urban rent is central to such urban redevelopment strategies. Closing the rent gap and cashing in on the produced revalorization of the development land is a clear leitmotiv in most projects. Table 3 summarizes this for three of the case studies, but it is also clearly evident in Copenhagen, Brussels, D ublin, Bilbao, A thens, Vienna, and Birmingham.

$U$ rban redevelopment is considered to be a central strategy in reequilibrating the problematic fiscal balance sheet of local government. Spatially focused policies aimed at producing increasing rent income, altering the socioeconomic tax basis, and producing profitable economic activities are among the few options available, particularly in a context in which the structure of fiscal revenues is changing rapidly. As the financial-services sector and profit-making via global speculative transactions drain major financial means and investments, such activities simultaneously escape government control and generate very limited local fiscal returns. In such context, the revaluation of urban land remains one of the few means open to local governments to increase tax returns. Of course, closing rent gaps or producing highrent-yielding spaces requires a production of built environments that permit significant surplus-value creation and/or realization. Yet the politics of rent-production through the production of the built environment has remained elusive in much of the recent literature on urban change.

Despite the rhetoric of market-led and privately covered investments, the state is invariably one of the leading actors in the process: in ten of the thirteen cases discussed in this paper, its role is outspoken. $\mathrm{R}$ isks are taken by the state, shared on occasion with the private sector, but given the speculative, real-estate-based nature of the projects, deficits are likely to occur. Traditional and well-documented processes of socialization of cost and risk and privatization of the possible benefits are central characteristics of most UDPs. While, in the past, invoking the social return of the projects legitimized such practices, they are now usually hidden behind a veil of creative accounting or by means of channeling funds via quasigovernmental organizations or mixed private/public companies. A s can be gleaned from Table 3, in the cases of Berlin's Adlershof and Lisbon's Expo 1998, the state became increasingly involved in covering deficits, a condition true in many of the other cases. It is only in the redevelopment of L ondon's South Bank that no state guarantee is involved and that the state only 


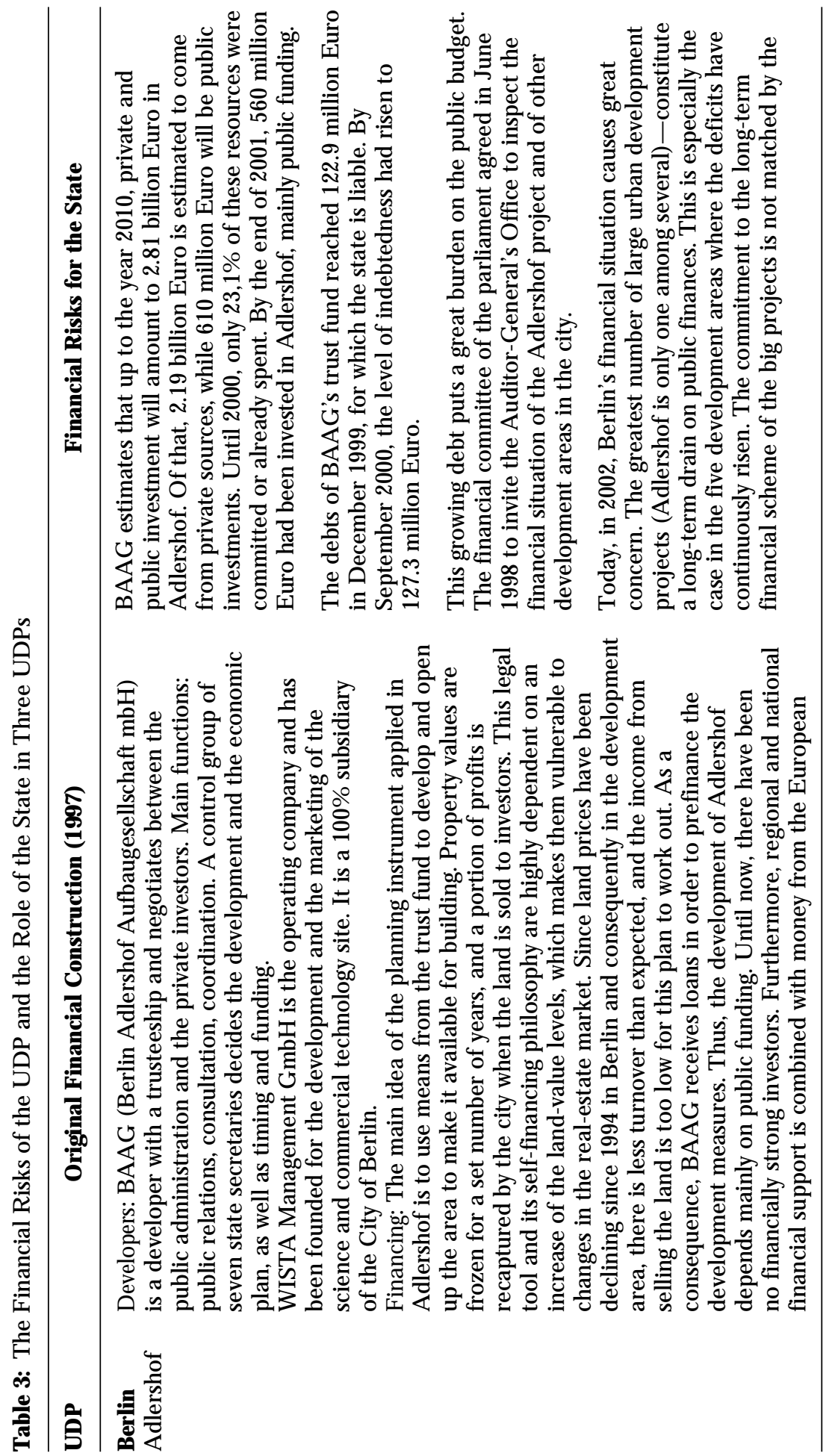




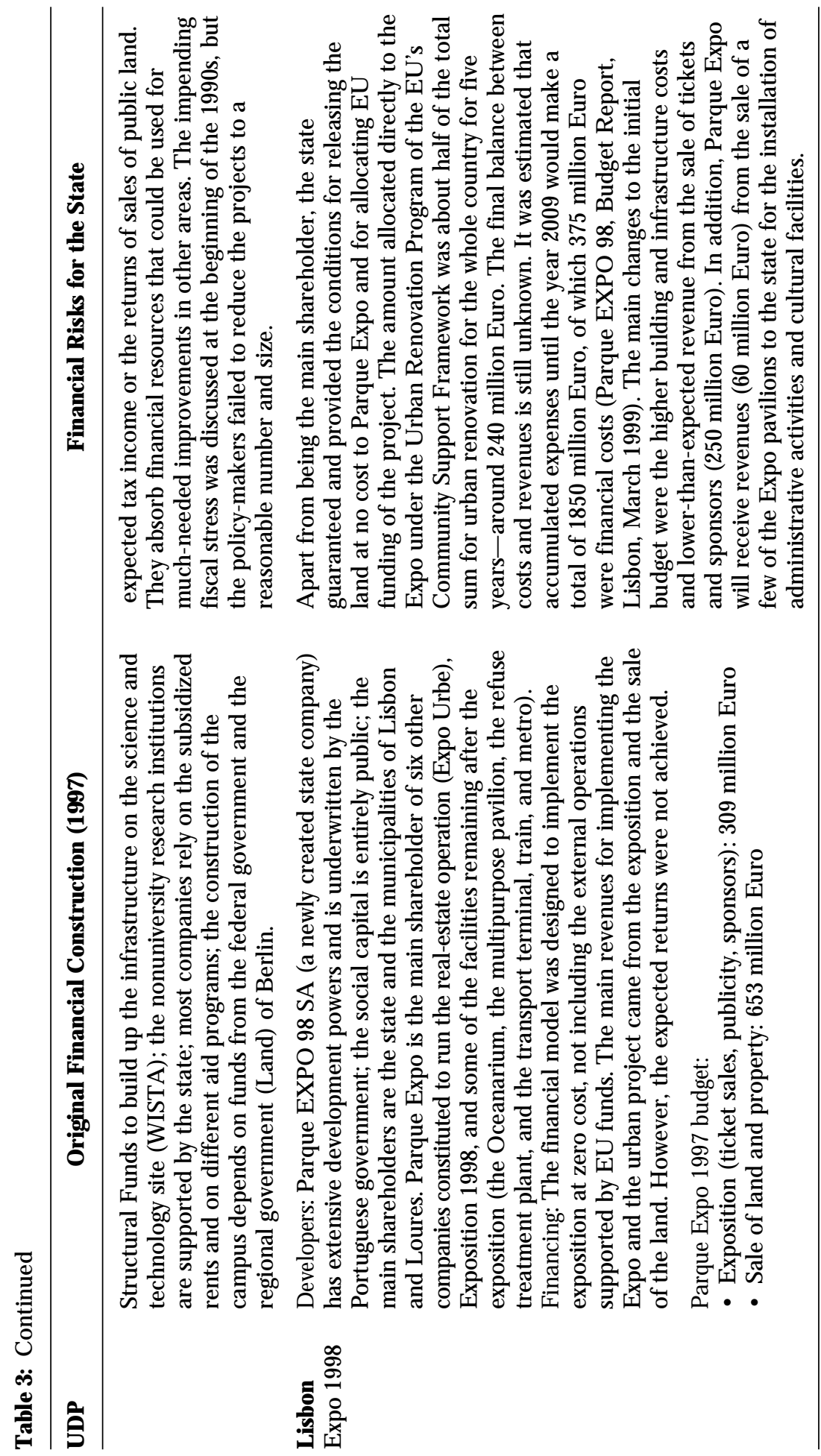




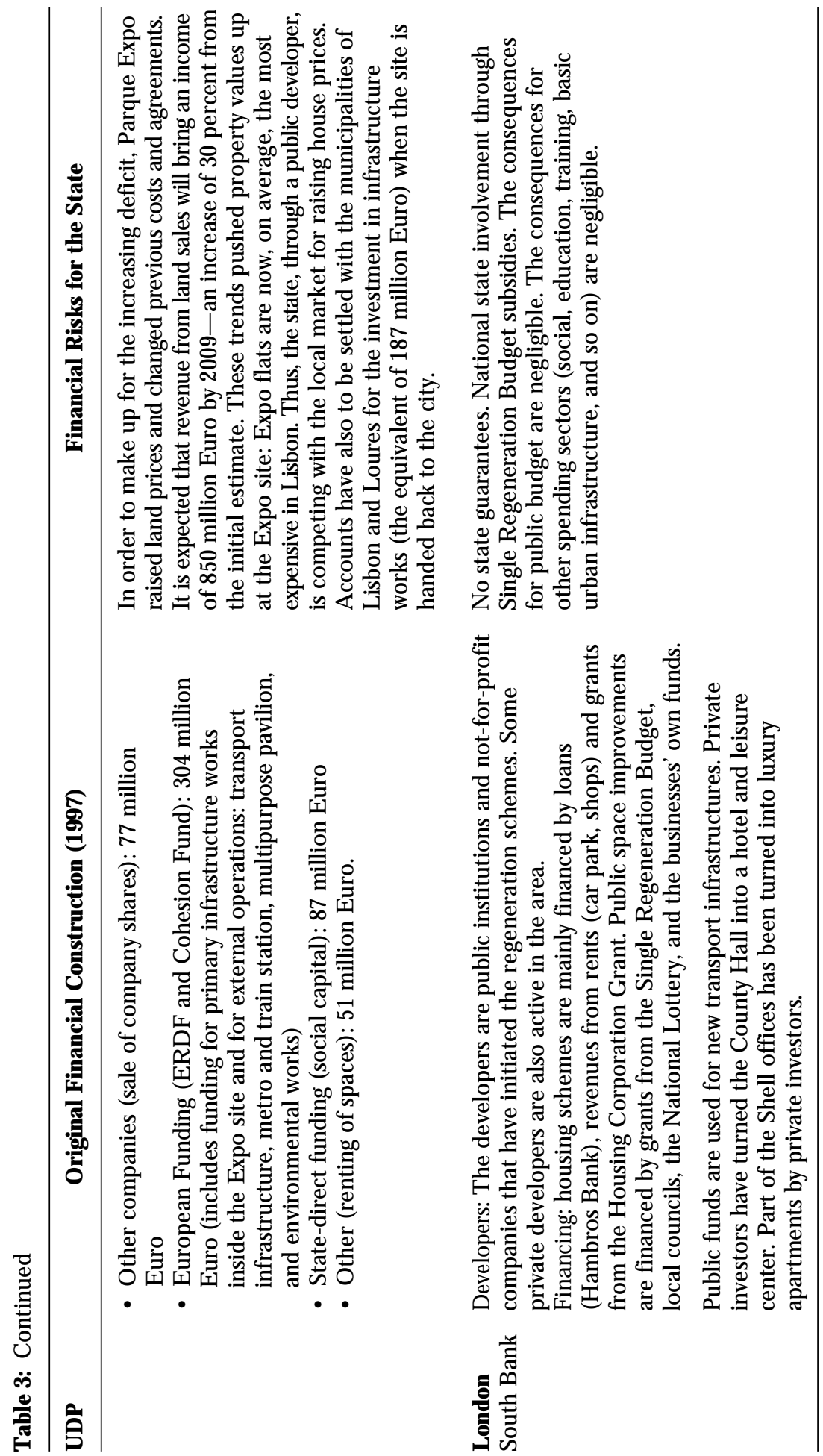


contributes through spending on social programs, training, and the provision of basic infrastructure.

A common theme is that most of the projects are decidedly rentextraction-based. Their success rests fundamentally on (1) the production of potential extra rent and (2) the subsequent realization of the produced land rent. The employment and economic activity generating consequences of the projects, however important they may turn out to be, are all subject to the successful appropriation of the "manufactured" land rent embodied in the new built environment. The public-private or public-public initiatives rework the urban fabric such that the potential rent from new developments is significantly higher than existing rent levels. Sinking capital and investment into the production of a new built environment revalues, at least potentially, the monetary value of the land and the built environment-benefits that are almost al ways reaped by the private sector. This is particularly noticeable in the cases of Dublin, Brussels, Bilbao, Berlin, A thens, Copenhagen, and Naples (for greater detail on these cases, see sources cited in the acknowledgments).

\section{Institutional Fragmentation and "Pluralistic" G overnance}

The newly emerging regimes of governing urban revitalization involve the subordination of formal government structures to new institutions and agencies, often paralleled by a significant redistribution of policymaking powers, competencies, and responsibilities. In the name of greater flexibility and efficiency, these quasi-private and highly autonomous organizations compete with and often supersede local and regional authorities as protagonists and managers of urban renewal. $M$ oreover, the fragmentation of agencies and the multiplicity of institutions, both formal and informal, are often portrayed as positive signs, suggesting enabling institutional thickness, a considerable degree of local embeddedness, and significant social capacity-building. In addition, these institutional and regulatory configurations are celebrated as a new form of governing, signaling a better and more transparent articulation between government (state) and civil society. The "stakeholder" participation on which partnerships are based becomes a normative model that is presented as a democratic forum that permits open and nondistorted communication and action.

Yet the actual configuration of such project-based institutions reveals an extraordinary degree of selectivity. A Ithough a varying choreography of state, private sector, and nongovernmental organization (NGO) participation is usually present (see Table 4 for a comparative overview), these forms of urban governance show a significant deficit with respect to accountability, representation, and the presence of formal rules of inclusion or participation. Indeed, accountability channels are often gray, nonformalized, and nontransparent, frequently circumventing 


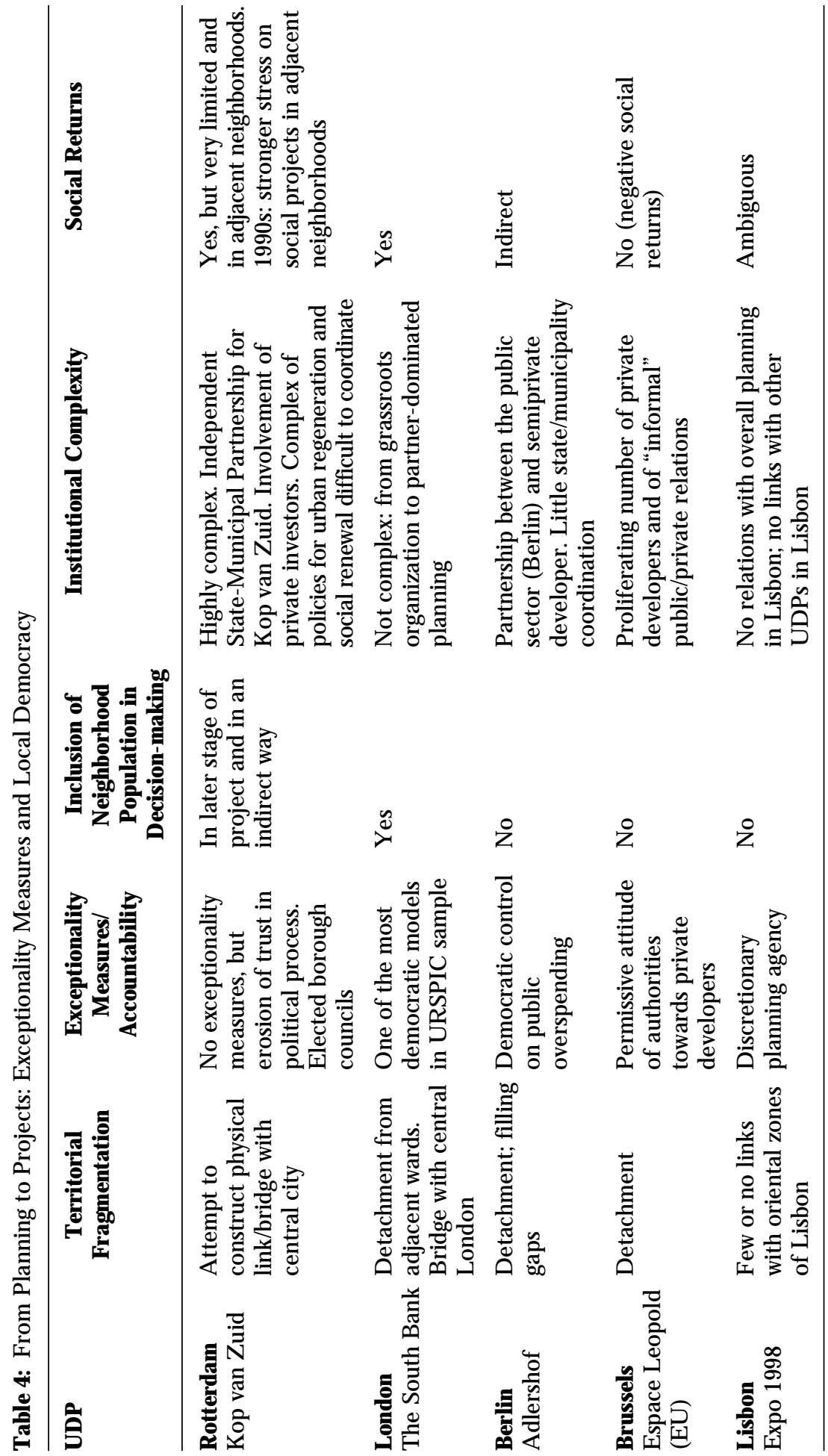




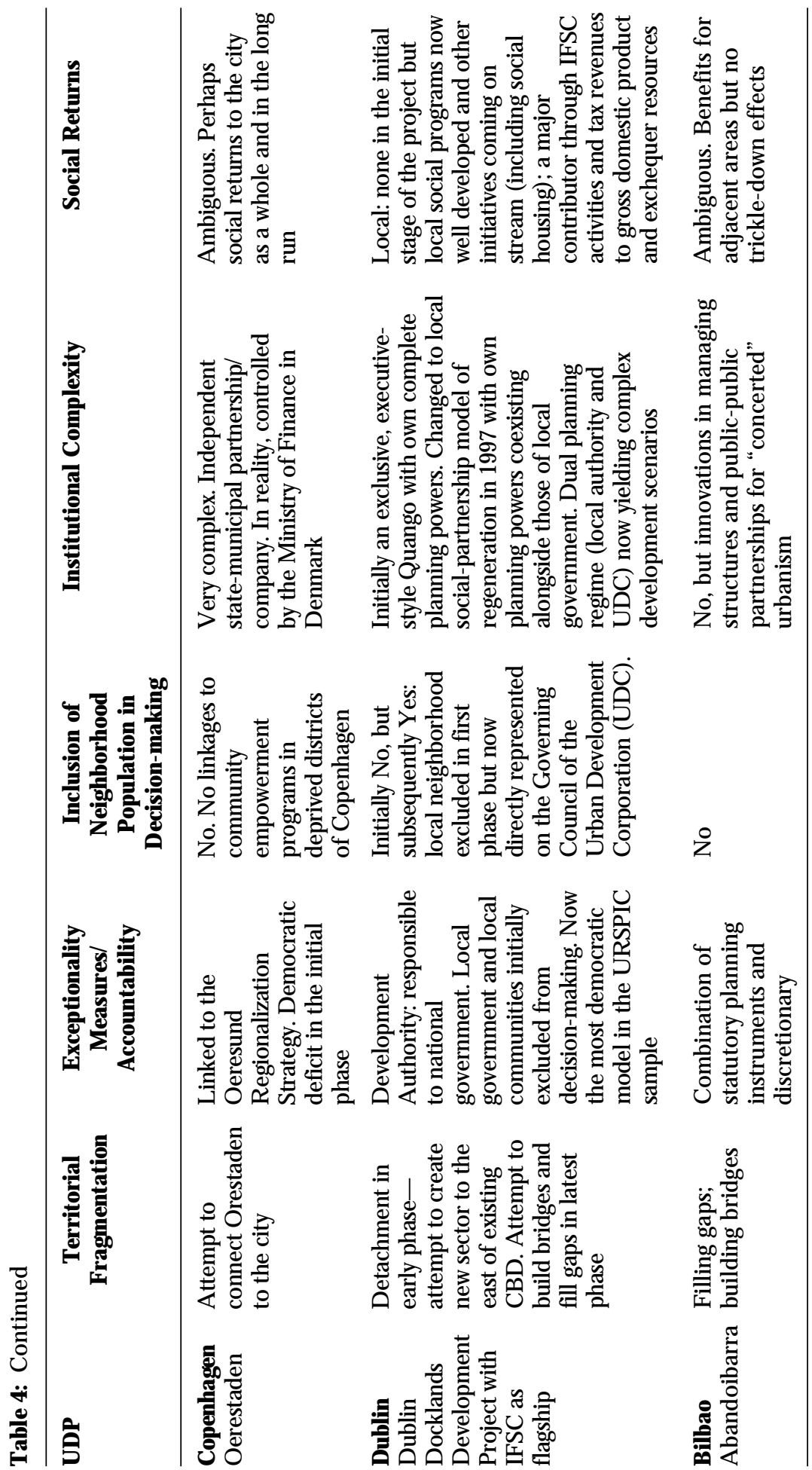




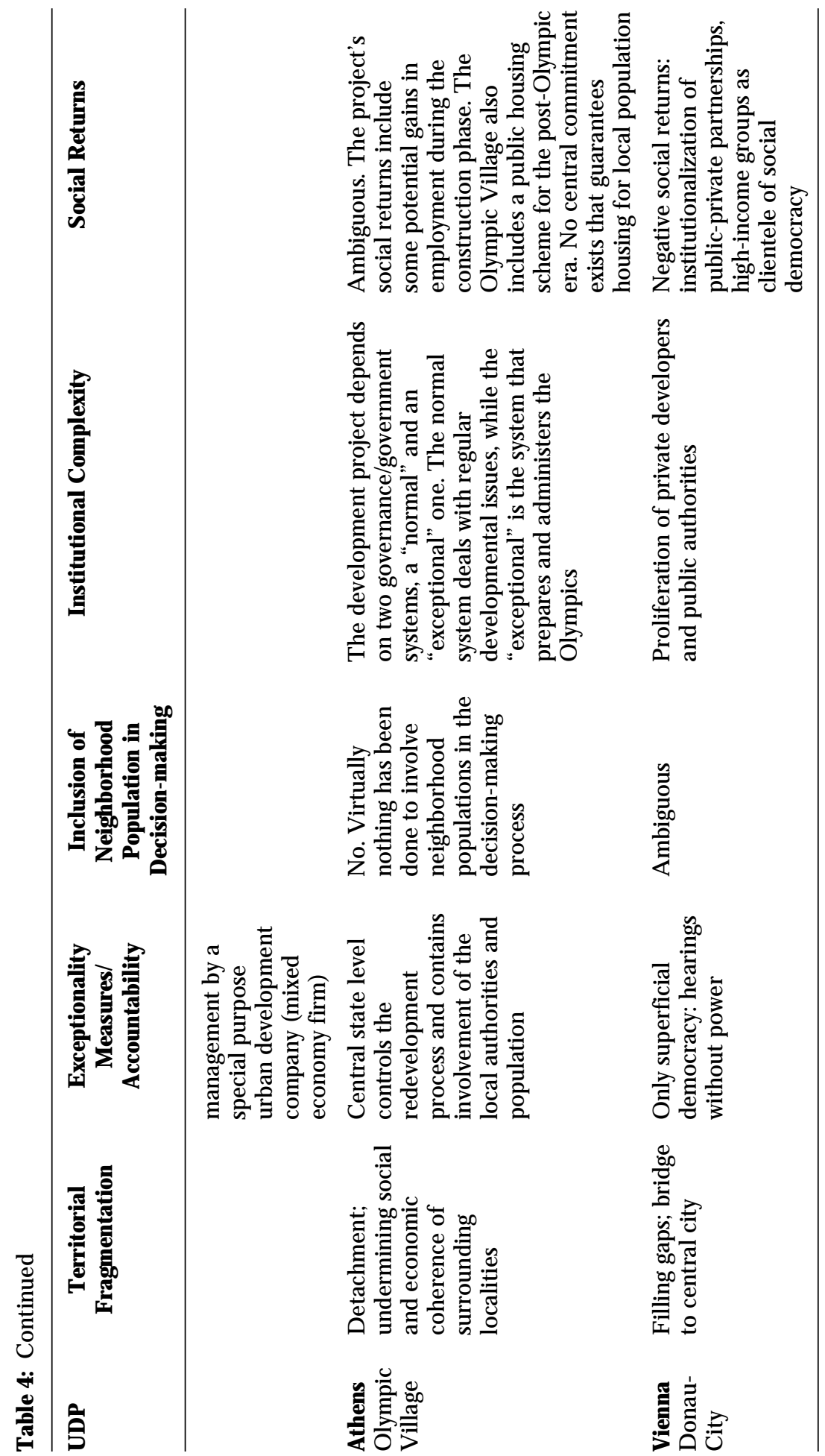




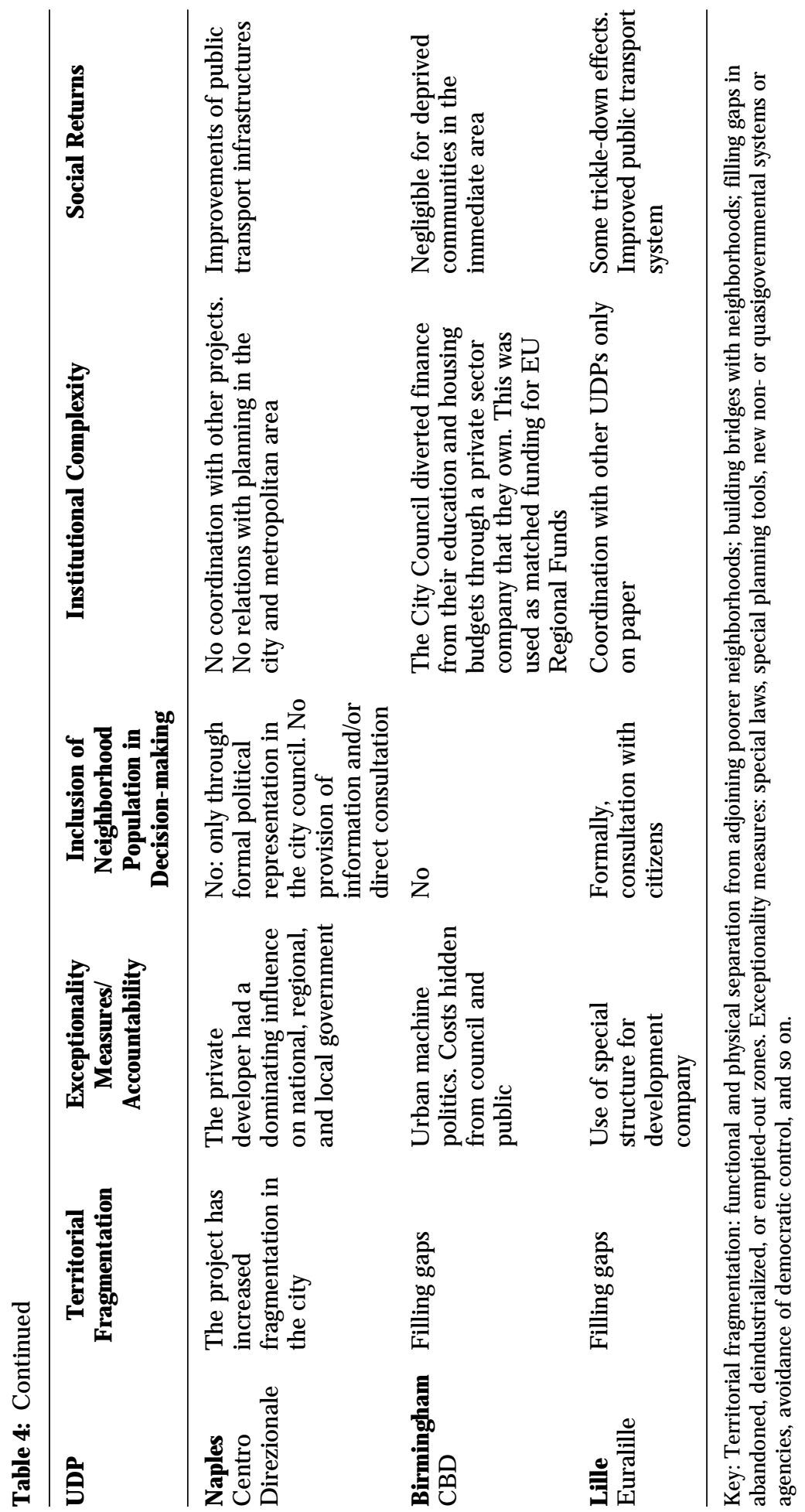


traditional democratic channels of accountability (eg to a representative elected body). As Table 4 suggests, the structures of representation of the participating partners are diffuse and unregulated. There are rarely formalized mechanisms of representation, and it is often difficult, if not impossible, to identify who represents what, who, and how. Finally-and most importantly-participation is rarely statutory, but operates through co-optation and invitation, usually by the key power brokers within the institutions. This invariably influences the regulatory environment, shapes the interventions, and produces a particular imagination of the urban in line with the demands, dreams, and aspirations of the included, while marginalized or otherwise excluded groups remain symptomatically absent. This process has become the dominant mode of institutional organization and suggests a shift from a system of representative urban government to one of stakeholder urban governance that is centered on newly established institutional arrangements. In our case studies (and this is especially clear in Berlin, A thens, Brussels, Lisbon, and Bilbao-see Table 4), a complex range of public, semipublic, and private actors shape an interactive system in which different, but allied, views and interests are "negotiated." Public-private partnerships epitomize the ideal of such cooperative and coordinated mode of "pluralistic" governance.

The emergence of a more fragmented and pluralistic mode of urban governance has also contributed to the redefinition of roles played by local authorities. In particular, it has served to reinforce the tendency towards a more proactive approach, letting local authorities act simultaneously as enablers, partners, and clients. At the same time, the new structures of governance also express the outcomes of an ongoing renegotiation between the different levels of governmentlocal, regional, and national-regarding competencies and powers in the management of urban revitalization. These institutions are bunkered against popular participation and influence by local community groups and, indeed, against democratic control and accountability. The cases of L ondon, Lisbon, B russels, and Bilbao reveal an extraordinary degree of autonomy and impermeability of the managing organizations. O ften, this organic autonomy has helped to reinforce the tendency to avoid a social and political debate over alternative paths and strategies.

Of course, as Table 4 illustrates, the level and degree of institutional reorganization of the systems and institutions of urban governance is highly variegated and context-dependent. $M$ oreover, as the process of planning and implementation is confronted with social protest or critique, institutional and organizational forms adjust or transform in order to maintain legitimacy, social cohesion, and sufficient political support. Despite the great diversity of local, regional, and national changes in the forms of urban governance and despite their often very different agendas (ranging from merely economic growth-based 
initiatives to integrated projects aimed at improving social conditions in the city), the project-based nature of these interventions is accompanied by new institutional configurations, characterized by power geometries that differ from those of the traditional arenas of government. A veil of secrecy pre-empts criticism and discussion, and a highly selective leaking of information is justified on the grounds of commercial confidentiality and technical impartiality. Indeed, a conspicuous feature of these large-scale projects is the relatively low resistance and conflict they generate. With the exception of Dublin and Brussels, there has been no major "grassroots" contestation of the UDPs. In this sense, the role of local growth coalitions is critical in framing a discourse of renewal, innovation, achievement, and success.

\section{From Planning to Projects}

Large-scale urban projects are often presented as project-focused market-led initiatives, which have replaced statutory planning as the primary means of intervention in cities. Planning through urban "projects" has indeed emerged as the main strategy to stimulate economic growth and to "organize innovation," both organizationally and economically (see Table 4). Large-scale projects and events are perceived as strategic instruments aiming at reshaping the city. A gainst the crisis of the comprehensive Plan- the classic policy instrument of the Fordist age - the large, emblematic Project has emerged as a viable alternative, allegedly combining the advantages of flexibility and targeted actions with a tremendous symbolic capacity. E ssentially fragmented, this form of intervention goes hand in hand with an eclectic planning style where attention to design, detail, morphology, and aesthetics is paramount. The emblematic Project captures a segment of the city and turns it into the symbol of the new restructured/ revitalized metropolis cast with a powerful image of innovation, creativity, and success. A nd yet, despite the rhetoric, the replacement of the Plan by the Project has not displaced planning from the urban arena. In fact, the case studies reveal that in most examples there is a strong strategic component and a significant role for planning. $H$ owever, in the process, there has been a drastic reorganization of the planning and urban policy-making structures and a rise of new modes of intervention, planning goals, tools, and institutions.

\section{Urban Projects and the Neoliberal Urban Order Visioning the City as an Elite Playing Field}

The U DPs included in our study have a variety of characteristics, but their sheer dimensions elevate them to central icons in the scripting of the image of the future of the cities in which they are located. 
Invariably, the main aspiration is to turn the city into a global competitive actor in the domain in which the elites feel it has some competitive advantage. Needless to say, the imagin(eer)ing of the city's future is directly articulated with the visions of those who are pivotal to the formulation, planning, and implementation of the project. Consequently, these projects have been and often still are arenas that reflect profound power struggles and position-taking of key economic, political, social, or cultural elites. The scripting of the project highlights and reflects the aspirations of a particular set of local, regional, and national-and sometimes also international-actors that shape, through the exercise of their socioeconomic, cultural, or political power, the development trajectories of each of the areas. As such, the UDPs can be considered as "elite playing fields," on which the stake is to shape an urban future in line with the aspirations of the most powerful segment(s) among the participants.

Clearly, the association of coalitions of elite players changes over time and from place to place, and alliance formation and break-up redefines development trajectories in important ways. Struggles for inclusion in or exclusion from the elite circles become pivotal in shaping wider process of social, cultural, political, and economic integration or exclusion. Each case study narrates the sociohistorical dynamics of alliances in the choreography of social-power struggles (for detailed accounts, see sources listed in acknowledgments). In conjunction with structural socioeconomic changes, these are instrumental in shaping the fortunes of urban environments, as they decide fundamental rights to housing, access to services, access to land and the like. A gain, the role of the state, the system of governance, and the position of the citizens vis-à-vis these institutional forms will be central in determining the mechanisms of inclusion/exclusion that are shaped by the new urban development trajectories. Yet, the underlying motive is to reinvigorate a successful accumulation strategy and accompanying hegemony of vision that revolves around the requirement to turn the projects into viable- that is, profitableeconomic ventures.

\section{From a Social to a Spatial Definition of Development:}

\section{Targeting Places rather than People}

A Imost all of the case-study projects pay at least rhetorical attention to social issues associated with the planning and implementation of the project. The assumed trickle-down mechanisms, occasionally accompanied by targeted policies to facilitate social inclusion processes (see Table 4), are considered of sufficient strength to permit a socially balanced and successful development. H owever, in contrast to the universal, inclusive, and blanket support policies that characterized Keynesian and welfare-state interventionism, economic regeneration 
is now primarily achieved via place-bound and spatially targeted redevelopment schemes. While national funding and incentives are diminishing, private development capital (from local, national, or extranational origin) is being mobilized for the implementation of territorially defined urban projects. In addition, given the reduction in universal welfare programs, the "territorial" approach or "targeted"area approach have replaced universal support structures. M oreover, the slimming-down of national social redistribution is accompanied by policies that direct funds and attention to particular social groups, identified on the basis of their location, their place, and the characteristics of their living environment. Similarly, the EU 's urban social programs take on an outspoken, spatially focused character.

In sum, there has been a shift from universalist to spatially targeted and place-focused approaches in the 1990s. Targeting policies/interventions to geographically circumscribed areas and to economically dynamic or promising activities is presented as a path to remedy socioeconomic exclusion. Indeed, in the policy discourse, UDPs are presented as instruments that can also help to overcome social exclusion. The official rhetorical attention to social issues is mobilized politically to legitimize projects, while the underlying and sometimes explicit objective is different. The assumption of trickle-down, however, does not hold true in a context characterized by an absence of regulatory (labor, financial, and income) standards or income redistribution systems at the national or E U level. This accounts, of course, for the significant differences in sociospatial inequality between, for example, D enmark, with its long social-democratic tradition, and the $U K$, with its much more liberal-conservative legacy. The targeting of spaces for "development" permits recasting particular social groups as problematic, excluded, marginalized, and nonintegrated. Consequently - so the official argument goes-strategies of integration and inclusion should be pursued by means of territorial, place-based policies, rather than through national or European-wide socioeconomic measures, redistribution, and political-economic strategies. From the perspective of this NU P, it is places that need to be integrated, not citizens; it is places that need redevelopment, not people that require jobs and income. Of course, the above is not a plea for dismissing community capacity-building and local-level initiatives, but they need to be framed in more general redistribution and regulatory polices at higher-scale levels- those of the national state and, more importantly, the E uropean U nion.

\section{Interurban Competition for National or European Funds}

A s most of the U DPs are nationally or EU (co-)funded (see Table 3), municipalities or other forms of local governance compete for targeted funding. In general, the concentration of public investments 
in these large-scale project locations involves redistributing resources away from other uses and areas. In addition, funds are allocated on a project-formulation basis, not on the basis of social needs or considerations of fostering the social economy. Either explicitly or implicitly, the competitive tendering process by national or international organizations favors projects that have a sound institutional and organizational basis capable of engaging in the complex tasks of project formulation, lobbying, negotiation, and implementation. This requires not only a set of sophisticated skills, but also significant financial resources, as well as easy access to the centers of power. All of this is usually not available to the weaker social groups and areas in the city, which are consequently falling behind and are dependent on ad hoc measures imposed from above. M oreover, given the need to foster alliances between often-rival economic and political elite groups to create the necessary hegemony of vision to compete successfully for state support and private investment, the development activities are often masked in a web of secrecy and hidden behind a screen of commercial confidentiality.

In the context of more targeted interventions and reduced universal social support, which is increasingly organized and conducted by and through elite coalition formation, public resources are drained from universal programs to targeted territorial projects geared at supporting a particular social configuration-a process that itself harbors exclusionary mechanisms. The misty organizational structures in B russels, the exclusive elite coalitions of Birmingham, and the shifting alliances in Copenhagen and Naples illustrate the variety of processes through which this takes place.

\section{Authoritarian Management, Exclusion, and Client Formation}

The new systems of urban governance-the quasigovernmental institutional framework based upon forging synergies between the public sector and the elite fractions of civil society-also justify the adoption of discretionary forms of management. Thus, the way the process develops creates the conditions for the establishment of centralized and more autocratic management, which privileges direct appointments. Thus, the role of lobbies, family ties, business connections, and forms of "clientelism" become dominant. These forms of coalition-formation at the level of project formulation and implementation accentuate a growing gap between actual governance and civil society, intensify processes of political exclusion, and promote a dual society in terms of a coalition of public/private interests on the one hand and a growing group of disenfranchised on the other. While the above suggests that growth machines, elite coalitions, and networks of power are centrally important in shaping development trajectories, it is evident from our case studies that different growth 
machines are associated with different interests and lead to different mechanisms of inclusion/exclusion.

Nonetheless, the "coalitions" of public and semipublic actors invariably produce an exclusive group involved in a common discourse on the progress of the project, a discourse that is not easily opened to public scrutiny or that would invite or permit dissidence. I mportant decisions and arrangements are made by steering committees, boards of directors of operating companies, nonaccountable quasigovernmental organizations, and the like, and are often kept away from public scrutiny. 0 utsiders are usually not tolerated. There is, at best, only a highly formalized form of public participation that maintains key power in the hands of the existing elite structure and even prevents newly emerging elites (such as, for example, immigrant entrepreneurs and an emerging group of sociocultural elites in the transnational communities in cities like B russels or V ienna) to enter the established networks of governance and dominant elite coalitions. These coalitions create a public discourse on the importance of the project and define it as a particular milestone in the shaping of the future of the city, and their interventions are presented as essential to maintaining a viable position in the interurban competition at a pan-E uropean or global scale.

The reactions of the local state to exogenous and endogenous pressures manifest in the establishment of these new forms of urban governance (public-private partnerships, development co-operations, new administrative structures, and new political forums) that circumvent, bypass, ignore, or marginalize certain social groups. The national state itself is often instrumental in shaping and organizing such exclusive growth coalitions and in providing the extraordinary regulatory environment in which they can operate outside a system of public accountability. In some cases, such as Copenhagen, Brussels, and $V$ ienna, such growth-coalitions reproduce or re-enforce existing but threatened corporatist forms of governance. Informal networks of a relatively small number of individuals occupying key positions in public administration, business, or design/architecture form a new field of power. In the tendering of large-scale projects, these networks are of crucial importance. N eedless to say, the projects are therefore closely associated with the interests of the particular coalition sets (and their clients); they are usually self-referential, closed circles that consolidate their power while preventing access to others.

\section{UDPs, Speculation, and the Production of $L$ and Rent}

As producers of urban space, UDPs are inherently speculative and hence highly risky, in the sense that their financial and economic viability depends on the future realization of the produced increased urban rents. Of course, the latter depend not only on the particular 
characteristics of the project or the vitality of the local economy, but also on national and international economic conditions. In addition, such projects provide opportunities to extract from the state (at a local, national, or EU level), in addition to its direct contributions, further resources in terms of public investment for infrastructures, services, and buildings. M ost of the project's development costs are supposed to be met from the sale or renting of land or buildingsrents the value of which has been jacked up through state support, re-regulation, zoning changes, infrastructure investment, and the like.

A ll this suggests that it is financially very attractive for real-estate developers to concentrate on developing projects for the more wellto-do customers, for housing as well as for businesses. In fact, the financial viability of market-driven urban revitalization projects is, of course, invariably predicated upon closing existing rent gaps by means of the production of a new built environment that is at least potentially capable of generating high income. The uncertain and, hence, intrinsically speculative character of the production of new land rent points towards the key role of the state as the preferred interlocutor for carrying the financial risks associated with such realestate-based urban restructuring (see also the chapters by Smith and Weber this volume).

Whether successful or not, the dependence on rent returns for the feasibility of UDPs invariably targets high-income segments of the population or potentially high-productivity-based economic activities and makes the success of the project dependent on the dynamics of the real-estate sector (see Table 5). This does not contribute to alleviating the process of social segmentation and exclusion and often leads to the creation of islands of wealth in an impoverished environment, resulting in the city becoming a patchwork of socioeconomically highly diversified and more mutually exclusive areas. To the extent that low-cost or social housing is included in the project, the lower revenue from such targeted housing policy undermines the financial feasibility of the project and requires, in turn, considerable state support or subsidies. Table 5 summarizes the relationships between real-estate development, the production of high rental returns, and a project's financing structure. Moreover, given the real-estate-based nature of these projects, the public funding is, through private rent appropriation, transferred to the private sector. Consequently, there is a flow of capital from the public to the private sector via the built environment, often without mediation by means of socially targeted policies or instruments.

\section{The City as Patchwork}

Given the often radically new socioeconomic functions associated with UDPs, a process of transfer and of dislocation of jobs inevitably 
Table 5: R elationship between Dynamics in the R eal-E state $M$ arket and UD P D evelopment: $N$ ine Cases

Project $\begin{gathered}\text { Real-E state Market, the Production of Rent, } \\ \text { and the Development of the UDP }\end{gathered}$

Berlin

A dlershof

Bilbao A bandoibarra

Brussels Leopold Quarter
The reunification of G ermany was decisive for the development of Berlin's real-estate market and triggered a sudden rush of initiatives from international and national investors and developers. This was re-enforced by a strong competition for attractive sites. Today, the Berlin real-estate market shows increasing supply-side reserves and demand structures that fall short of expectation. These developments have had a major impact on the progress and pace of the project implementation in A dlershof. Here, a high volume of office and housing sites has been planned without considering the decreasing demand. $D$ ue to the restraint of private investors, project development has slowed down in A dlershof.

A s in most other cities throughout Spain, since the mid-1980s, the real-estate market in Bilbao has experienced an extraordinary boom. During the 90 s, housing prices in the city continued to rise, although the rate of growth decreased in the last third of the decade. R eal-estate prices in A bandoibarra both benefited from and contributed to this boom. In the less than four years that separated the beginning of redevelopment works and the marketing of the first housing land slots, land prices in A bandoibarra more than doubled (2.3 times). R ealestate price increases have spread throughout the city, but they tend to be proportionally higher in A bandoibarra's adjoining neighborhoods. And, while it cannot be said that land price increases in the city are exclusively related to A bandoibarra's redevelopment, it is nonetheless certain that this scheme is contributing significantly to this trend as well as to the alteration of housing prices differentials among different neighborhoods across the city.

$\mathrm{D}$ ue to the continuous demand for additional office space in the L eopold Q uarter - a demand led by the EU institutions, but also by both national and international banking and insurance sectors-rental values have systematically increased over the past decades. R ents in the L eopold Q uarter are now amongst the highest in the country (up to $200 \mathrm{E}$ uro per $\mathrm{m}^{2}$ ). The increasing demand for office space has also generated speculative activities in the area: remaining residential blocks are systematically bought by property developers and eventually demolished and replaced with offices, regardless of land-use planning regulations. 0 ther residential pockets have been upgraded and made available for wealthy (international) residents, or are now de facto (and illegally) used as offices for smaller organizations (for example, lobby groups and law firms). G lobally operating real-estate agents (such as J ones L ang W ootton and $\mathrm{H}$ ealey \& Baker) have come to dominate the L eopold Q uarter market, while construction and property development remains mainly in Belgian (and F rench) hands. 
Table 5: Continued

Project

\section{Real-E state M arket, the Production of Rent, and the Development of the UDP}

Copenhagen O restaden

Lille

E uralille

Vienna

Donau-City

Naples

Centro

Direzionale
In general, the prices in the housing market skyrocketed during the second half of the 1990s and the social geography within the city has become more polarized. There still exists an important social-housing sector, but the role of this sector has gradually declined, because housing construction subsidized by the municipality and the state has almost stopped since the beginning of the nineties. The municipal housing policy has increasingly been used as a tool to regulate the tax base of Copenhagen, favoring the middle classes. The U DP follows this trend.

E uralille and other U D Ps in the Lille agglomeration did not lead to skyrocketing increases of land and housing prices. $\mathrm{H}$ owever, inside the agglomeration, real-estate market dynamics have produced a displacement of lower-middle-class and working-class population to "cheaper" areas. Gentrification projects in particular (first V ieux Lille, then E uralille, W azemmes, and Moulins) with more offices, exquisite services, and middle- to upper-class housing estates, led to local price rises, driving deprived population groups to other neighborhoods, especially to the south of Lille or even outside the agglomeration. The U DP has contributed to this growing spatial differentiation of real-estate and rental values.

R ents skyrocketed in the second half of the 1980s and have been stagnating since then. This can be explained by a contradictory movement. On the one hand, there still exists an important public-housing sector. H ousing construction subsidized by the municipality was intensive until 1996, and restrictive rent laws were applied until 1982. On the other hand, liberal regulation is advancing: subsidies for construction of housing have been dramatically reduced over the last years. Furthermore, publicly subsidized housing is increasingly oriented towards the upper middle classes. The UDP is a paradigmatic case illustrating these changes.

D uring the 1980s, prices in the real-estate market grew dramatically to reach record levels in 1991 and 1992, particularly in selected central areas. They subsequently declined almost as fast as they had previously risen, continuing to fall until 1997, when the first signs of recovery appeared and prices stabilized or began to increase again. A partments in the Centro D irezionale di Napoli (CD N) became available at the peak of the market price for prime location units and thus could be expected to yield quite significant returns. The developer, however, sold $90 \%$ of the residential units to a state-run pension fund for the employees of public companies and guaranteed his return. By law, only families working for state agencies are entitled to rent those apartments, and rental prices are set lower than the market price according to the rules of the 
Table 5: Continued

Project

\section{Real-Estate M arket, the Production of Rent, and the Development of the UDP}

1978 Fair R ent Act. This decision removed these units from the sale and rental markets, creating a separate segment that is somewhat insulated from market dynamics. The project had also a depressing effect on the value of building land for other office projects in the city.

Dublin

Docklands

Development

Project (with

IFSC as

flagship)

\section{London}

South Bank
Property demand in both the housing and office markets, both within the UDP site and in the surrounding neighborhoods, has grown rapidly in the 1990s and land prices in the area have soared due to the presence of the IFSC. With companies queuing to get into the successful IFSC site as the economy boomed in the 1990s, the intense demand for office space squeezed other real-estate markets, most notably the provision of social and affordable housing within and around the UDP. A verage house prices tripled between 1989 to 1999, while the provision of social housing evaporated due to the post-1986 retrenchment of public-sector welfare spending. The housing situation is particularly acute in the docklands U D P and neighboring areas. L ocal residents cannot compete with investors or the predominantly young professionals who purchase or rent the limited supply of private residential units available in the area. The result has been gentrification of the initial UDC site and the exclusion from the life of the area, through the property market, of many of the latest generation of the indigenous population.

The real-estate market on the South $B$ ank is subject to contradictory tendencies. On the one hand, the South Bank is one of the most expensive spots in central London because of its central location opposite the city and W estminster. In terms of real-estate prices, it is exceeded only by those two areas. On the other hand, the South Bank's community development group, Coin Street Community B uilders, owns 6.5 acres of land on the South Bank, which is designated for the construction of co-operative housing schemes and public spaces. This has a certain downward effect on real-estate prices. $\mathrm{H}$ owever, the recently opened new underground line (the Jubilee $L$ ine) has significantly improved the South Bank's connections with the rest of Central London and will certainly have an upward effect on real-estate prices. Furthermore, the successful "reimagineering" efforts through public space improvements and consistent place marketing, together with the opening of major nearby attractions such as the new T ate Gallery, will also have an effect on real-estate prices. $M$ eanwhile, the housing market remains strongly dominated by Local A uthority housing $(38 \%)$, housing co-operatives $(28 \%)$, and semipublic institutions (17\%). O nly $15 \%$ of residents live in privately owned houses and $2 \%$ in privately rented flats. A nother estimated 2000 adults live in hostels, on the streets, and in other nonpermanent accommodation (estimates for 1994). 
takes place. Spatial labor markets become out of joint or are mismatched. Targeted labor-market policies might remedy some of this disjuncture, but the sheer scale of labor-market restructuring often implies prolonged stress on the labor market combined with painful processes of adaptation and, frequently, a growing separation between remaining local communities and the incoming new workforce. This separation is often accentuated through now-generalized processes of deregulation of labor markets at national and $E U$ levels. This leads to a double-edged dualization of labor markets. Increasingly, dual or segmented labor markets are seen, with a group of highly paid and skilled executives on the one hand and large groups of less secureoften-informal-workers on the other, and many other categories in between. The segmentation of labor markets, which is facilitated by the national deregulation of labor-market rules and other changes in the national regulatory frameworks, becomes cemented in and expressed by the socioeconomic composition of the U DPs. The inclusion of the existing labor pool proves difficult or impossible, while retraining and targeted labor-market entry policies tend not to be very successful, despite the prolonged support for such programs.

This socioeconomic restructuring, combined with a mosaic of newly constructed built environments with their associated increased rents, produces urban islands, a patchwork of discrete spaces with increasingly sharp boundaries (gated business centers, leisure, or community spaces). This is re-enforced through a combination of physical, social, and cultural boundary formation processes. The overall result is the consolidation of a fragmented city, which accompanies the reorganization of the sociospatial fabric of the urban agglomeration (see also $M$ acL eod this volume). In some cases, this mosaic takes the form of suburbanization of poverty, while internal differentiation accentuates sociospatial differentiation and polarization, a process that often takes outspoken racialized forms (notably in Brussels, Berlin, Rotterdam, and Vienna).

\section{Conclusion: Neoliberal Urbanism and Democratic Deficit}

$U$ rban regeneration and development policies in the E uropean city, in the context of national and EU -wide tendencies towards the implementation of neoliberal socioeconomic policies, brought about critical shifts in domains and levels of intervention and in the composition and characteristics of actors and agents, institutional structures, and policy tools. $O$ ver the last decade and a half, urban regeneration policy has become an increasingly central component of urban policy. For the most part, urban regeneration schemes based on large-scale U D Ps have emerged as a response to urban restructuring processes associated with the transformation of production and demand conditions locally, nationally, and globally; they generally combine physical 
upgrading with socioeconomic development objectives. In particular, such projects have become an integral part of neoliberal policies to replace more traditional redistribution-driven approaches. The search for growth and competitive redevelopment has become the leading objective of the NU P in an attempt to reassert the position of cities in the emerging global economy. E nhancing the competitive advantage of cities is seen as largely dependent on improving and adapting the built environment to the accumulation strategies of a city's key elites. Therefore, physical reconstruction and economic recovery tend to go hand in hand and, very often, are perceived as quasi-simultaneous processes: megaprojects are viewed as providing a solid foundation for fostering future growth and functional transformation. At the same time, urban revitalization is projected beyond the cities' limits and linked to regional recovery and internationalization strategies.

H ow do the various U D Ps reflect this NU P? Figure 1 already summarized various critical dimensions of this policy. M ost UDPs have caused increased physical and social fragmentation in the city. N otable exceptions include Kop van Zuid in Rotterdam, which established a physical-functional-but not a social- "bridge" with the rest of the city, and 0 erestaden in Copenhagen, which has-after prolonged protest-recovered some housing and service functions that would otherwise have been lost. The other projects have primarily filled gaps for the (higher) middle-class real-estate and consumption-good markets, but not for other, usually poorer and/or immigrant sections of the urban population. While economic gaps have been "plugged," greater social disparities and sociospatial fragmentation have been produced.

A central issue involved in urban regeneration policies is the relation of UDPs to existing planning instruments and regulations. While these projects are generally inserted into existing statutory planning guidelines, the initial conception, design, and implementation lies at the margins of formal planning structures. The framework of "exceptionality" associated with these initiatives favors a more autonomous, if not autocratic, dynamic marked by special plans and projects that relegate statutory norms and procedures to a secondary and subordinated place. $M$ any local authorities and national governments justify the exceptionality of a UDP on the basis of different factors: scale, the emblematic character of the operation, timing pressures, the need for greater flexibility, efficiency criteria, and the like. "Exceptionality" is a fundamental feature of the new urban policy, based on the primacy of project-based initiatives over regulatory plans and procedures. These changes involve, among other things, the emergence of new policy tools, actors, and institutions, and they have important consequences for urban policy-making in general and for local democracy in particular. These projects exemplify like no 
other the trends towards a new local mode of regulation of urban (re)development and management shaped by the pressures of competitive restructuring and changing social and economic priorities, as well as by major political and ideological shifts. Indeed, the emergence of NUP rests significantly on the establishment of new forms of intervention at the local level that, to a large extent, constitute a rupture with traditional forms. Entrepreneurialism is about the public sector running cities in a more businesslike manner, in which institutions of local governance operate like the private sector or are replaced by private-sector-based systems. Indeed, the NU P is closely associated with fundamental shifts from traditional government structures to a more diffused, fragmented, and flexible mode of governance. The combination of different spatial and administrative scales in urban policy-making and the increasing fragmentation of competencies and responsibilities is one of its most striking aspects. In most cities, the full dimension of urban regeneration cannot be adequately apprehended without reference to the multiplicity of agents, the articulation of spatial scales at which they operate, and the fragmentation of agency responsibility within the urban arena. In some cases, this trend seems to be linked to a shift from hierarchical relationships (in terms of the traditional territorial hierarchy of statutory planning procedures) to a more collaborative and stakeholderbased, but often socially highly exclusive, scheme in which partnerships between and networks of a variety of elites play a key role. H owever, at the same time, fragmentation and diversity are also accompanied by tendencies towards the exclusion of certain groups and collectives from participating in the decision-making process. A democratic deficit emerges as a central element of this strategic approach.

The fragmentation of the mode of governance redefines the role and position of local authorities. Indeed, in the name of greater flexibility and efficiency, these new institutions compete with and often supplant local and regional authorities as protagonists and managers of urban renewal. In fact, the new governance structures express the outcomes of an ongoing renegotiation between the different levels of government-local, regional, national, and E uropean-and between public and private actors over competencies, decision-making powers, and funding. The establishment of these new structures frequently involves massive redistribution of policy-making powers, competencies, and responsibilities away from local governments to often highly exclusive partnership agencies, a process that can be described as the "privatization of urban governance."

The fragmented character of many of the UDPs- which are often self-contained, isolated, and disconnected from the general dynamics of the city-contrasts sharply with the strong emphasis on coordinated action of different actors, the encouragement of partnerships, and the 
building of networks and support coalitions. These are presented as providing a potentially superior form of urban management, more flexible and efficient, and thus better adapted to the competitive trends of global urban change. The trend towards a more flexible and network-oriented approach is often perceived as a validation of "bottom-up," less hierarchical, and more participatory dynamics. However, participation is often limited to selected professionalsarchitects, planners, economists, engineers, and so on-who have become increasingly influential, while the nonprofessional sector and less powerful social groups are largely excluded.

In the same way, the shift from centralist, formalized, bureaucratized, hierarchical, top-down planning approaches to decentralized, more horizontal, informal, flexibilized, bottom-up, and network planning approaches has gone hand in hand with increasing inequality in access to decision-making. The role of experts is strengthened at the expense of a diminishing role of the public in general and of traditional organized groups in particular, with a consequent loss of democratic accountability. Yet these new forms of governance are often legitimized on the basis of their superior ability to offer a more inclusive, nonhierarchical, and participatory approach to planning. However, the realities of a network based on the primacy of the expert and dominated by the fusion of technical, economic, and political elites suggest a selective exclusion of major sections of civil society in terms of access to decision-making processes.

As is succinctly summarized in the Viennese case study, "the advantage of these personalized networks is mutual trust and high adaptability; its disadvantage is a decrease of public accountability, a weakening of civil society and an erosion of the existing parliamentary democracy." In those cases in which neighborhood movements reacted to the initial lack of local democracy (Rotterdam, Dublin), participation had to be partly restored, and neighborhood demands, as well as concerns about social issues, climbed a few notches up the policy priority list. Nevertheless, the limited and spatially targeted interventions associated with project-based urban restructuring policies prevent these movements from transcending the localized issues associated with a project's implementation and from translating these social demands into more generalized policy models at higher spatial scales. This is arguably the most significant implication of the NUP. The downscaling of urban policies to place-specific interventions in a context in which traditional redistributional policies are being reduced at higher-scale levels forces social movements to operate through localized actions. This, in turn, militates against the urgent need to translate these place-specific actions and demands into more general social and economic programs articulated at the national, EU, or international scale. 


\section{Acknowledgments and References}

The analysis presented in this paper draws upon the results of a thirtymonth research project on U rban Redevelopment and Social Polarization in the City (URPIC). The support of the European U nion's IV th Framework Program is gratefully acknowledged.

The project was co-ordinated by Frank Moulaert, A rantxa Rodriguez, and E rik Swyngedouw. A Ithough the present paper cannot provide full empirical details on each of the thirteen city cases, detailed case-study results have been published in the following journals: Journal of European Urban and Regional Studies 8(2) 2001, Geographische Zeitung 89 ( 2 and 3), 2002, Rassegna I taliana di Sociologia 41(4), 2001, and Ciudad y Territorio-Estudioas Territoriales (CiTET), November 2001 and forthcoming 2002.

Case studies will also be published in Urbanising G lobalisation, by F Moulaert, A Rodriguez, and E Swyngedouw, Oxford U niversity Press, forthcoming 2002.

The project reports, images and further details on each of the projects can be found on the World-Wide Web at http://www.ifresi.univlillel.fr (select Programmes de R echerche and then select UR SPIC).

$M$ any of the insights reported in this paper come from a large number of participants in this project. We would like to acknowledge our debt in writing this contribution to all those who worked with us on this project. Their fieldwork, data collection, interviews, and surveys provided the foundation and material and many of the insights for this project, and their thoughts and writings were used extensively in the preparation of this paper. We are very much indebted to: Serena Vicari and Lucia Cavoli (Naples), Pavlos Delladetsimas (A thens), J oão Cabral (Lisbon), Elodie Salin and Thomas Werquin (Lille), Elena M artinez (Bilbao), G uy Baeten (L ondon and Brussels), Louis A lbrechts (Brussels), $\mathrm{H}$ artmut $\mathrm{H}$ auserman and Katja Simons (Berlin), A ndreas Novy, Vanessa Redak, and Johachim Becker (Vienna), J ohn A nderson (Copenhagen), B rendan Bartley and Kasey Treadwell Shine (Dublin), Alan Middleton and Patrick Loftman (Birmingham), and Gerard Oude Engberink and Frank Miedema (Rotterdam).

We are also grateful to N eil Brenner and to Nik Theodore for their support, editorial suggestions, and patience, and to the referees for their comments and suggestions. Of course, none of them should be held accountable for the contents of this paper.

\section{Endnotes}

${ }^{1}$ This paper is based on a large number of research reports from the U R SPIC project, written by more than twenty-five academics working on each of the thirteen cases. The paper presented here digests material that comes from all of these papers, and parts were actually written by one or another of our collaborators. R eferences in the original 
research documents often come from our partners' national sources (D anish, G reek, I talian, Spanish, G erman, and so forth). We considered including an exhaustive transnational literature list, but this would have been unacceptably long and not all that useful for many people. A Iternatively, we could have opted for inserting just a standard list of mainly A nglo-Saxon references, but this would not do justice to the wide variety of national insights on which we drew. Therefore, we chose not to have references at all, but decided instead on the following. The names of the individuals involved in the project are listed in the acknowledgments. All project reports, individual case studies, references, images, and other materials are available on the W orld-W ide W eb at http://www.ifresi.univ-lille1.fr; select Programmes de Recherche and then select U RSPIC). In addition, five special journal issues (of which two are in English) and a forthcoming book (to be published in 2002) give detailed information on various aspects of the research for many of the case studies (see A cknowledgments section for details). In fact, all of the case studies are covered in one way or another in these publications. People interested in particular details of and further information on any of the case study projects and cities can consult either the W eb site or these publications.

Erik Swyngedouw is U niversity Reader in Economic Geography in the School of Geography and the Environment, Oxford U niversity, and Fellow of St Peter's College. He is also an A ssociate Fellow of the $\mathrm{E}$ nvironmental Change Institute. $\mathrm{H}$ is research has focused on the political-economy of the capitalist space-economy, on urban change and globalization, and on the political-ecological of water. $\mathrm{He}$ is coeditor of a forthcoming book on U rbanising G lobalisation ( $O$ xford U niversity Press, 2002) and another on Participatory G overnance in the European Union (Leske \& Budrich, forthcoming). He has coedited (with Andy Merrifield) The Urbanisation of Injustice (L ondon, L awrence and W ishart; N ew York, N ew York U niversity Press, 1996).

Frank M oulaert is a Professor of E conomics at the $U$ niversity of Lille I, France. $\mathrm{He}$ is head of the $\mathrm{E}$ uropean $\mathrm{PhD}$ program in Industrial and L abour E conomics and R egional D evelopment and coordinates two research projects under the $E U$ 's Framework $V$ program. $H$ is latest book (together with $A$ Rodriguez and others) is G lobalization and Integrated Area Development in European Cities (Oxford U niversity Press, 2000). His current research focuses mainly on local development and social innovation.

Arantxa Rodriguez, A ssociate Professor at the Faculty of E conomics of the U niversity of the Basque Country (Bilbao-Spain), focuses her research on the dynamics of socioeconomic restructuring and spatial development planning in the Basque Country. Since the mid-1980s, she has been directly involved in the production of several urban plans in that area. She has also carried out research on the articulation between physical, functional, and economic planning and local economic development strategies. She is coauthor, with Frank M oulaert, of G lobalization and Integrated Area Development in European Cities 
(Oxford University Press, 2000). Her other publications include "N uevas políticas y nuevos instrumentos para la revitalización metropolitana," in Encuentros de Desarrollo L ocal y E mpleo (Coruña, 1998), and "Planning the Revitalisation of an Old Industrial City: U rban Policy Innovations in Metropolitan Bilbao," in Local Economic Development in E urope and the A mericas (edited by $C D$ emazière and P Wilson, M ansell, 1996). 